\title{
Analysis of The Influence of Employee Stock Ownership Program (ESOP) Application of Company Financial Performance
}

\author{
Fitri Handayani ${ }^{*}$, Yurniwati ${ }^{2}$ \\ ${ }^{1,2}$ Andalas University Faculty of Economics \\ *Correspondence email: fitri.handayanii09@gmail.com; yurniwati.fekon.unand@gmail.com
}

\begin{abstract}
This study aims to examine the effect of implementing the Employee Stock Ownership Program (ESOP) on the company's financial performance. and differences in the company's financial performance when issuing ESOPs and not issuing ESOPs. The implementation of ESOP is proxied by the proportion of ESOP and the price of execution, the company's financial performance is proxied by ROE, NPM, and OPM. The research was conducted on companies listed on the IDX and have adopted the ESOP in 2012 to 2016. The sampling method uses purposive sampling. To test the effect of applying ESOP on performance. The results of this study indicate that the number of ESOP Provisions given has no effect on ROE, NPM, and OPM. ESOP execution prices affect the value of ROE and NPM but do not affect the value of OPM. There is no difference in the value of ROE, NPM, and OPM when the company issues ESOP and does not issue ESOP.
\end{abstract}

Keywords: Employee Stock Ownership Program (ESOP); Execution Price; Company Financial Performance

\section{INTRODUCTION}

The company's main objective is to increase the value of the company and maximize the prosperity of shareholders. The value of the company will be high in the eyes of shareholders when the financial performance of the company is always increasing. The company's financial performance can be measured by analyzing financial statements and conducting assessments with financial ratio analysis. One way that companies can do in an effort to improve the company's financial performance is by implementing an employee ownership program (Employee Stock Ownership Program). The Employee Stock Ownership Program (hereinafter abbreviated as ESOP) is a contractual opportunity provided by a company where employees can buy a certain amount of company stock,

The relationship between ESOP and company performance is discussed in agency theory. Agency theory is a contract that occurs between principal and agent (Jensen and Meckling, 1976). The shareholders (principal) will employ agents (in this case management) to run the company and act in the interests of shareholders (Anthony, 2009). But in reality shareholders and management have different interests because each individual acts according to their own interests. This creates a conflict of interest between the principal and agent. To overcome this conflict of interest the principal provides an incentive or compensation to management both in financial and non-financial forms. One form of financial compensation given to employees is ESOP. With the implementation of the ESOP it can equalize employee and company incentives by providing opportunities for employees to participate in creating shareholder wealth. ESOP can also motivate managers to try projects that are at risk because managers / employees can get a share of the benefits from these projects (Subramanyam and Wild, 2009).
Increased management ownership in the company causes all decisions taken by management also have a direct impact on management. Therefore, the existence of a program of share ownership by employees will align management interests with shareholders (Jensen, 1976). In addition, ESOP can make managers in taking decisions impartially between the interests of management or shareholders so as to improve the company's financial performance (Pugh 2000).

ESOP given to employees can encourage employees to continue to perform optimally so as to achieve the targets set by the company. When the targets set by the company have been met, the ESOP can be given to employees as an incentive (Financial Accounting Standards Board, 2015). The amount of ESOP given to employees depends on the performance achieved by employees, this causes the emergence of employee motivation to improve performance continuously (Kameswari, 2014).

In applying ESOP, in addition to determining the amount of ESOP given, the company also determines the price of implementing an ESOP to be issued. The exercise price (execution price) is determined on the date of the ESOP award with an amount below the current stock market price (Astika, 2012). Low ESOP prices and below market prices can encourage employees or managers to raise stock market prices by increasing company performance.

In a theoretical level there is a debate about the relationship between ESOP and corporate financial performance. Pugh (2000) found that companies that implement ESOP have better financial performance than companies that do not issue ESOP. Sesil and Maya (2005) also prove that the application of ESOP has a positive impact on small companies. This is because in small companies providing motivation for employees has a clear relationship between actions and 
performance. It also proved that the performance of companies that implement ESOP is better than the performance of companies of the same size but does not apply ESOP.

Iqbal (2001) who found that the application of ESOP would be able to improve operating performance which is proxied by operating income, which means that the application of ESOP has a positive effect on the company's financial performance. Research conducted by Astika (2005) proves that the application of ESOP has a positive effect on company performance in the coming year.

Santhy (2009) found that there were differences in company performance before and after the implementation of the ESOP. The results of this study indicate that the average value of return on assets has increased after the implementation of the ESOP. From this study it can be seen that the purpose of implementing employee stock ownership programs has been fulfilled, namely to motivate employees to improve company performance. Another study was conducted by Aboody (2010) who examined the impact of ESOP on company performance as represented by the CFO (Cash from Operation) and Operating Income proxy. This research proves that the application of ESOP has a significant influence on company performance which can be seen in the increase in operating income and cash from operations for five years.

Bacha (2009) who examines whether companies that have ESOP have better performance than companies that do not have ESOP. Bacha (2009) found that companies that apply ESOP have high average returns but also have lower stock volatility than similar companies but the difference between the two is not statistically significant. Besides this research found that the financial performance of companies that apply ESOP has decreased operating performance in small companies.

Budiman (2017) examines the effect of the execution price and ESOP on the company's financial performance by moderating managerial ownership. The results of the study prove that ESOP has a positive effect on company performance but ESOP has a negative effect on company performance which is moderated by managerial ownership. While the execution price does not significantly influence the company's performance and the execution price does not significantly influence the company's performance which is moderated by managerial ownership.

Based on the description that has been explained, the formulation of the problems in this study are as follows: (1) Does the ESOP affect the financial performance of companies listed on the Indonesia Stock Exchange? (2) Does the ESOP Execution Price affect the financial performance of companies listed on the Indonesia Stock Exchange? (3) Are there differences in the company's financial performance when issuing ESOPs and when not issuing ESOPs? The purpose of this research is to find out whether there is an influence of ESOP on the financial performance of companies listed on the Indonesia Stock Exchange, to find out whether there is an effect of the ESOP execution price on the financial performance of companies listed on the Indonesia Stock Exchange,

\section{Agency Theory}

Agency theory is a basis for understanding the relationship between the Employee stock Ownership program and company performance. The main focus on agency theory is on the principal and agent. In agency theory explained that the principal will hire another party, namely an agent to run the company and act in the interests of the principal (Anthony, 2012). Whereas Jensen and Meckling (1976) stated that an agency relationship is a contract that occurs between one person or several employer (principal) who employs another person (agent) to perform a service, delegating authority by making decisions on agents. In a company the shareholders are the principal and the CEO or management is the agent.

In terms of principal's interests, the maximum return on investment is realized by the high profits generated by the company so that the dividends distributed are also high. While agents want to provide high incentives or bonuses for their performance in running the company. Principal will provide incentives to agents based on company performance which is reflected in the high profits generated so that agents will do everything they can to improve the company's performance and the resulting profits.

Because of differences in interests between the principal and agent, agency costs will arise incurred by the principal for the supervision of the agent. Agency conflicts can be overcome by increasing management or employee ownership of the company (Bathala, 1994). Efforts that can be made by companies to overcome agency conflicts are by applying ESOP to companies (Baridwan, 2006). ESOP is an effective step that can be taken to overcome agency problems (agency problem) and reduce agency costs through aligning the interests of executives with shareholders (Brenner et al., 2000). In this way agency costs can also be reduced because with the ownership of shares by management it is hoped that management will have the same goals as shareholders.

Zimmerman (1986) proposed three hypotheses related to agency theory, bonus plan hypothesis, debt / equity hypothesis, and political cost hypothesis. The bonus plan hypothesis explains the employment contract between the owner of the company (shareholders) and his managers. Debt / Equity hyphotesis explains the loan contract between the creditor and the company (management). While the political cost hypothesis 
describes the relationship between the company (management) and the government.

\section{Employee Stock Ownership Program}

Employee Stock Ownership Programis a plan to suspend employee benefits by acquiring company stock (Klein, 1987). ESOP is a long-term company policy that involves employee psychology in the form of a stockbased compensation program (Astika, 2005).

The objectives of holding an ESOP in a company include (Bapepam, 2002):

a. Give rewards or rewards to all employees and other parties who contribute to improving company performance

b. To create common goals and interests between shareholders and employees or management so that there will be no more conflicts of interest between agents and principals

c. Increase motivation and commitment of company employees due to employee ownership in the company so that it is expected to increase productivity and company performance.

d. Attract, retain and motivate employees

e. As a means of human resource programs to support the success of the company's business strategy for the long term, because the ESOP is a form of compensation based on the principle of incentives, aimed at giving employees rewards the amount of which is associated with measures of company performance or shareholder value.

In addition to the five objectives above, ESOP also has an effect on employees, companies and society (Freeman, 2007), the effect of ESOP adoption for employees that can improve employee welfare, job stability for the better, and increase job satisfaction, organizational commitment, motivation and participation . For securities companies, the application of ESOP is to increase productivity and profitability and increase the likelihood of the company continuing (going concern). As for the community, the effect of applying ESOP is to increase economic growth and reduce social inequality.

The reasons for implementing ESOP are (Subramanyam, 2009):

1. To improve performance by giving employees ownership of the company because it unites employee incentives with the company

2. Means to attract talented employees so they can work hard

3. Is a form of employee compensation that does not have a direct impact on cash.

\section{Execution Price}

Bapepam (2002) explains that the exercise price is the price set by the company on the date of the issuance of stock options determined at one hundred percent of the fair market price of the company's shares. ESOP is an option given by a company to employees at a price that was fixed at the time of adoption. The execution price in general is not much different from the market price of the company's shares when the option is issued.

Provision of ESOP and ESOP Execution prices can motivate employees to perform better over time. This is because the ESOP award is based on the company's performance in the year before the ESOP was issued.

\section{Company performance}

The company's performance is a picture of the financial condition in a certain period both regarding aspects of raising funds and channeling funds, which are usually measured by indicators of capital adequacy, liquidity, and profitability. With good performance of a company, the company is considered to be able to manage and utilize all its resources effectively and efficiently. Financial performance can also be used as a material consideration in making decisions for shareholders (stakeholders).

Performance measurement is used by companies to make improvements over their operational activities in order to compete with other companies. Financial performance analysis is a critical review process of reviewing data, calculating, measuring, interpreting, and providing solutions to the company's finances in a certain period.

The financial ratios used in this study are profitability ratios. Profitability ratios are ratios used to measure a company's ability to produce a profit or profit from the use of its capital. Some profitability ratios are:

\section{Return in Equity (ROE)}

This ratio measures the company's ability to generate profits based on the capital owned by the company. ROE shows what percentage of profits earned by the company when measured from owner's capital. This ratio is a measure of profitability from the perspective of shareholders. Shareholders make an investment to get a return on their investment and this ratio can reflect the rate of return of any investment made by shareholders (Brigham, 2008). The higher the value of ROE, the better financial performance of the company.

\section{Net Profit Margin (NPM)}

This ratio is the profit of sales after calculating all costs and income taxes. NPM serves to measure the rate of return on net income to net sales. The value of NPM illustrates how well a company uses its operating costs because it links net income with net sales. NPM is often used to evaluate the efficiency of a company in controlling expenses related to net sales (Gitman, 2009). The higher the value of NPM, the better the operating performance of the company. 


\section{Operating Profit Margin (OPM)}

Operating profit margindescribe the pure profit received for each rupiah from every sale made by the company. OPM can be said purely because the value of OPM comes from the company's operating results by ignoring financial and tax obligations such as interest costs and income tax costs. OPM measures the percentage of each sale remaining after all costs and expenses other than interest costs, taxes, and preferred stock dividends. The higher the value of the OPM ratio, the better the financial performance of the company (Gitman, 2009).

\section{Hypothesis Development}

The Effect of Employee Stock Ownership Program (ESOP) on Company Financial Performance

The relationship between ESOP and corporate financial performance can be explained by agency theory. In the agency theory explained that the relationship between the principal (owner) and agent (management) can lead to conflicts of interest between each party. To resolve this conflict of interest, the company owner needs to provide compensation to management. One form of compensation given to management or employees is the Employee Stock Ownership Program. The purpose of implementing the ESOP is to increase the motivation of employees in each company to perform better than that to create a sense of belonging to the company so that the goals between management / employees can be aligned with the objectives of the owner of the company. In research Sesil and Maya (2005) found that the provision of ESOP to employees has a positive impact on the company's financial performance. Another study conducted by Kim (2016) also found that the application of ESOPs to companies had an influence on the company's financial performance but the effect was relatively small. However, different from the research conducted by Bacha (2009) which found that the application of ESOP negatively affected the company's operating performance, which means that after the implementation of ESOP the company's operating performance decreased in small companies. In this study, financial performance is proxied by ROE, NPM, and OPM Another study conducted by Kim (2016) also found that the application of ESOPs to companies had an influence on the company's financial performance but the effect was relatively small. However, different from the research conducted by Bacha (2009) which found that the application of ESOP negatively affected the company's operating performance, which means that after the implementation of ESOP the company's operating performance decreased in small companies. In this study, financial performance is proxied by ROE, NPM, and OPM Another study conducted by Kim (2016) also found that the application of ESOPs to companies had an influence on the company's financial performance but the effect was relatively small. However, different from the research conducted by Bacha (2009) which found that the application of ESOP negatively affected the company's operating performance, which means that after the implementation of ESOP the company's operating performance decreased in small companies. In this study, financial performance is proxied by ROE, NPM, and OPM

From the explanation above, it can be concluded that the hypotheses that can be developed are:

H1: Employee Stock Ownership Program affects the value of Return on Equity

H2: Employee Stock Ownership Program affects the value of Net Profit Margin

H3: Employee Stock Ownership Program affects the value of Operating Profit Margin

\section{The Effect of Execution Price on Company Financial Performance}

Execution Price is the price of implementing the ESOP that was set at the time the ESOP was issued. The profit received by the employee from the implementation of the ESOP is the difference between the execution price and the company's stock price if the employee sells his shares. Therefore, company employees will try to raise the price of the company's shares in order to increase the stock price. One way that can be done is to improve the company's performance for the better so that it can affect stock prices. Previous research by Kameswari (2014) found that execution prices affect company performance both in the grant year and in the coming year. This can occur because the execution price that is set lower than the stock market price encourages employees to increase share prices by increasing performance so that the benefits gained from the ESOP program become greater. In contrast to Budiman's research (2017), which found that the price of ESOP execution had no effect on company performance.

From the explanation above, it can be concluded that the hypotheses that can be developed are:

In this study, financial performance is proxied by ROE, NPM, and OPM

H4: Execution Price influences Return on Equity

H5: Execution Price affects the Net Profit Margin value

H6: Execution Price affects the value of Operating Profit Margin

Differences in Financial Performance Companies that adopt ESOPs when issuing ESOPs and when they do not issue ESOPs

Employees who participate in the ESOP program will usually perform well when the company issues ESOP, this happens because the stock option program will be implemented if employees can meet certain 
Fitri Handayani dan Yurniwati, Analysis of The Influence of Employee Stock Ownership Program (ESOP) Application of Company Financial Performance

requirements of the company, one of them by improving performance in accordance with company targets.

Research conducted by Santhi (2015) found that there were differences in company performance when implementing ESOP and before applying ESOP. In this research the company's financial performance is proxied by three different financial ratios so that the hypotheses developed are also different, different.

H7: There is a difference in Return on Equity of ESOP companies when issuing ESOP and not issuing ESOP H8: There are differences in ESOP companies' Net Profit Margin when issuing ESOP and not issuing ESOP

H9: There is a difference in the Operating Profit Margin of ESOP companies when issuing ESOP and not issuing ESOP

\section{METHODS}

The research design uses descriptive and verification methods. The type of data used in this study is secondary data where secondary data used by researchers is sourced from websites on the internet namely the Indonesia Stock Exchange (IDX) websitewww.idx.co.id in the form of financial statements and annual reports of companies recorded in the period 2012-2016

\section{Population and Sample}

The population in this study are companies listed on the Indonesia Stock Exchange and published on the website www.idx.co.id with the period 2012-2016 with the number of companies currently registered at 560 companies.

The sample in this study are companies that have adopted ESOP in the 2012-2016 period. The sample used was taken using the Purposive Sampling method, which is a sampling technique based on criteria determined by the researcher. The sample criteria used in this study are as follows:

1. Companies listed on the Indonesia Stock Exchange in the period 2011-2016 for which complete data are available for analysis purposes.

2. Companies that implement the ESOP program in the study period are from 2012-2016.

3. Companies that implement the ESOP and publish complete financial statements from 2012-2016.

4. Companies that have issued ESOP in 2012 and have complete information about the implementation of ESOP

\section{Variables and Measurements \\ Independent Variable}

1. Employee Stock Ownership Program (X1)

The Employee Stock Ownership Program is proxied by the proportion of stock options granted to employees, namely by comparing the number of shares granted for the ESOP program with the total number of shares outstanding and owned by the company.

Proportion of ESOP $=\frac{\text { Jumlah Opsi saham diberikan }}{\text { Jumlah Keseluruhan Saham yang beredar }}$

2. Stock Option Execution Price (X2)

Execution Price is the price set by the company to exercise employee stock options. The exercise price for most of the exercise of stock options is set at $100 \%$ the fair market price of the shares at the date of option grant (Bapepam, 2002).

\section{Dependent Variable (Y)}

1. Return in Equity (ROE)

This ratio measures the company's ability to generate profits based on the capital owned by the company. ROE or also called the profitability of own capital is used to measure how much profit belongs to the owner of capital. ROE value is calculated using the following formula:

$$
\text { ROE }=\frac{\text { Net Income after Tax }}{\text { Total Equity }}
$$

2. Net Profit Margin (NPM)

This ratio is the profit of sales after calculating all costs and income taxes. This margin shows the comparison of net income after tax with sales. NPM illustrates how much net income is generated from each rupiah of income. The formula to calculate NPM is:

$$
N P M=\frac{\text { Net Income }}{\text { Revenue }}
$$

3. Operating Profit Margin (OPM)

This ratio is a financial ratio that aims to measure the company's ability to generate profits before being reduced by interest costs and taxes. The higher the value of this ratio in a company means the company's financial performance is getting better. The formula for calculating OPM is:

$$
O P M=\frac{\text { Operating Income }}{\text { Revenue }}
$$

\section{Analysis Method \\ Descriptive statistics}

Descriptive statistics are statistics used to analyze data by describing the data that has been collected as it is without intending to make generally accepted conclusions or generalizations (Djarwanto, 2005). Descriptive statistics can be in the form of maximum, minimum, average, and standard deviation. 


\section{Classic assumption test}

\section{Normality test}

In this study to test whether the data are normally distributed or not used the Kolmogorov Smirnov test and the normal probability plot test. In the Kolmogorov Smirnov test, the criterion used is a twotailed test that compares the $\mathrm{p}$-value produced with a specified level of significance

2. Multicollinearity Test

The purpose of the multicollinearity test is to find out whether there is a correlation between independent variables in the regression model. A good regression model is the absence of correlation between independent variables (multicollinearity does not occur).

3. Heteroscedasticity Test

The purpose of the heteroscedasticity test is to test whether in a regression model there is an unequal variance in residuals from one observation to another. If the variance of the residuals from one observation to another it is called homokedastisitas while if different is called heteroscedasticity (Ghazali, 2006). A good regression model is if heteroscedasticity does not occur. In this study to test whether or not there is heteroscedasticity is to use a glacier test.

4. Autocorrelation Test

To detect the presence or absence of autocorrelation, in this study using the autocorrelation test with the Durbin Watson Test (DW test).

\section{Multiple Regression Analysis}

In this study the method of data analysis uses multiple regression with the aim to see the effect of independent variables on the dependent variable. In this study, regression analysis is used to determine the effect of independent variables namely the Proportion of ESOP and Execution Price on the dependent variables namely ROE, NPM, and OPM. The multiple regression analysis model in this study is shown by the equation:

$\mathrm{Y}=\alpha+\beta 1 \mathrm{PE}+\beta 2 \mathrm{HE}+\mathrm{e}$

Where :

$\mathrm{Y} \quad=$ Financial Performance (ROE, NPM, and OPM)

$\mathrm{PE} \quad=$ Proportion of ESOP

$\mathrm{HE} \quad=$ ESOP Execution Price

$\alpha \quad=$ Constant

$\beta 1, \beta 2=$ Regression Coefficient

$\mathrm{e} \quad=$ Error

\section{Hypothesis testing}

1. Coefficient of Determination (Adjusted R2)

The coefficient of determination functions to see the extent to which all independent variables can explain the dependent variable. The value of the coefficient of determination is between 0-1 where if the value approaches 1 then the effect of the independent variable on the dependent variable is getting stronger.

\section{Statistical Test t (t-test)}

Partial regression analysis testing is performed by $\mathrm{t}$ test (t-test). $\mathrm{T}$ statistical test aims to determine whether the independent variable partially has a significant effect on the dependent variable.

3. Statistical Test F (Simultaneous Test)

F statistical test shows whether all the independent variables included in the model have a joint influence on the dependent variable (Ghozali, 2011).

4. The Whitney Man Test

The Mann Whitney test aims to determine whether there are differences in the average of two unpaired samples. In this test the number of samples used does not have to be the same. The Whitney Man test is part of non-parametric statistics so no data that are normally distributed are needed.

\section{RESULTS AND DISCUSSION}

From the sample selection results chosen by purposive sampling, 15 samples of companies have adopted the ESOP in 2012-2016.

To test the comparison of the company's financial performance when issuing an ESOP and when the company did not issue an ESOP the sample used was companies that implemented ESOPs between 2012-2016 and did not apply an ESOP at least twice during the research year. Based on predetermined criteria, a sample of 10 companies was obtained.

\section{Data Analysis Results Descriptive statistics}

The results of descriptive statistics of each independent variable and the dependent variable can be seen in Appendix 8.

The proportion of ESOP and execution price has the lowest value of 0.00 , this is because there are companies that do not issue an ESOP in one year of observation so that the value becomes 0.00 . While the highest value of the proportion of ESOP is 2.69. The highest Execution Price is Rp. 6096. For the average value of the ESOP Proportion and Execution Price respectively 0.5279 and $R p 839.69$.

Company performance is proxied by ROE, NPM, and OPM. ROE has the lowest value of -42.65 . In NPM the lowest value is -25.70 . This value illustrates that the net loss obtained by the company in 2016 reached $25.70 \%$ of total net sales. And the OPM ratio has the lowest value of -15.47 .

For the highest value of each proxy, the company's financial performance is 29.37 . The highest NPM value is 190.27 which is the NPM value of MNC Land Tbk Company where this value is a very high value because the net profit generated by the company is greater than the sales. And for OPM the highest value is 61.17. while for the average of each proxy the financial 
performance of the company is worth $3.5275,7.5464$, 9.7151, and 14.7533 .

\section{Classic Assumption Test Results}

1. Normality test

The normality test in this study uses the Kolmogorof Smirnov normality test. The test results can be seen in appendix 9 .

For the three models used, the models for measuring ROE, NPM, and OPM are all normally distributed with a significance value of 0.200 or $20 \%$ for ROE, 0.200 or $20 \%$ for NPM, and 0.200 or $20 \%$ for OPM. For details on the normality test results table for each model, see Appendix 9.

The sample (n) used for the ROE model is not 75 samples, this is due to the presence of extreme data which causes the data to be abnormal, so a cut outlier is performed. After the cut outlier data is ignored, there are 3 pieces of data that cause the total sample (n) used in the test to be 72 . This is also done in the NPM and OPM models. In NPM, there were 3 data that were ignored, and one data was OPM.

2. Multicollinearity Test

The results of the Multicollinearity Test calculation can be seen in Appendix 9. Based on the results of data processing above, it can be seen that all independent variables in the study have a toll clearance value above 0.10 , namely in the ROA, ROE, NPM, and OPM equations the value of the tollarance from the ESOP Proportion and Execution Price of $0.717,0.722,0.723$ and 0.711 , all of which are smaller than 0.10 . So it can be concluded that the regression equation model in this research model does not have a multicollinearity problem so that the regression model is feasible to be used in research.

3. Heteroscedasticity Test

Heteroscedasticity test results with the glacier test model can be seen in Appendix 9. sig values indicate values greater than 0.05 for each test model, namely ROE, NPM, and OPM. So it can be concluded that in each test model there is no heteroscedasticity.

4. Autocorrelation Test

The test results for each model can be seen in Appendix 9. From the autocorrelation test table above it can be seen that only NPM is free from autocorrelation, while the ROE and OPM models cannot be concluded because the $\mathrm{dW}$ value is between the $\mathrm{dL}$ and $\mathrm{dU}$ values. For the ROE model if done with the Runs Test, an Asymp value can be obtained. Sig of 0.097 where this value is greater than 0.05 which means that in the ROE model there is no autocorrelation.

As for the OPM model, even though using the Runs Test, the same conclusion is obtained because of the Asymp value. Sig (2-tailed) is below the value of 0.05. Therefore, in order to be free from autocorrelation, the transformed data was performed with the Cochrane Orcutt Test so that the $\mathrm{dW}$ value became 1.905 where this value is between the $\mathrm{dU}$ and 4-dU values. So it can be concluded that the OPM regression model does not have autocorrelation.

\section{Multiple Linear Regression Analysis}

In this study the data analysis method used is multiple linear regression analysis because it aims to see the effect of variable $X$ namely the Number of ESOPs and Price of Execution for variables $\mathrm{Y}$ namely ROE, NPM, OPM. The multiple linear regression analysis model in this study has three models, namely the ROE model, the NPM model, and the OPM model. The results of the multiple linear regression test in this study for each model are as follows:

Table 1. The results of the multiple linear regression test

\begin{tabular}{|l|r|r|r|}
\hline \multirow{2}{*}{ Model } & \multicolumn{3}{|c|}{ Unstandardized Coefficients } \\
\cline { 2 - 4 } & \multicolumn{1}{|c|}{ ROE } & \multicolumn{1}{c|}{ NPM } & \multicolumn{1}{c|}{ OPM } \\
\hline (Constant) & 5,544 & 3,425 & 8,094 \\
Proportion of ESOP & -1.504 & $-1,082$ & 2,204 \\
Execution Price & 1,042 & 1,016 &, 785 \\
\hline \multicolumn{4}{|l|}{ a. Dependent Variable: NPM } \\
\hline
\end{tabular}

From the results of the multiple regression analysis that has been done, we get the values of each coefficient for each model as follows:

1. ROE model

$$
\mathrm{Y}=5,544-1,504 \mathrm{PE}+1,042 \mathrm{HE}+\mathrm{e}
$$

2. NPM Model

$$
\mathrm{Y}=3,425-1,082 \mathrm{PE}+1,016 \mathrm{HE}+\mathrm{e}
$$

3. OPM Model

$$
\mathrm{Y}=8.094+2,204 \mathrm{PE}+0.785 \mathrm{HE}+\mathrm{e}
$$

\section{Hypothesis Test Analysis Results}

1. Determination Coefficient Test

Based on the results of statistical tests conducted, the Adjusted R Square ROE value is 0.075 , NPM is 0.070 , and OPM is 0.068 , which indicates that the magnitude of the ability of independent variables, namely the proportion of ESOP and the price of execution can explain the dependent variable, namely ROE, NPM, and OPM that is equal to $7.5 \%, 7 \%$, and $6.8 \%$ and the remainder are influenced by other variables outside the research model.

\section{Statistical test $t$}

The results of the statistical $t$ test that have been done, show that the significance value of the proportion of ESOP for all three models is 0.407 for ROE, 0.565 for NPM, and 0.347 for OPM. These results indicate that the proportion of ESOP has no effect on ROE, NPM, and OPM. 
While the significance value of the execution price is 0.009 for ROE, 0.013 for NPM, and 0.117 for OPM. These results indicate that the execution price affects ROE and NPM but does not affect OPM.

3. Statistical Test $F$

The results of statistical tests that have been done show that the significance value of the $\mathrm{F}$ test for each proxy is $0.026 \mathrm{ROE}, 0.031 \mathrm{NPM}$, and 0.031 OPM. This value indicates that the proportion of ESOP and the price of execution jointly affect ROE, NPM, and OPM.

4. Mann Whitney Test

Man Whitney test results for the three dependent variables namely ROE, NPM, and OPM can be seen in the following table:

Table 2. Test results for the three dependent variables namely ROE, NPM, and OPM

Statistics Test

\begin{tabular}{|l|r|r|r|}
\hline & \multicolumn{1}{|c|}{ ROE } & NPM & \multicolumn{1}{c|}{ OPM } \\
\hline Mann-Whitney U & 65,000 & 75,000 & 72,500 \\
Wilcoxon W & 120,000 & 130,000 & 127,500 \\
Z & $-1,540$ & $-1,100$ & $-1,210$ \\
Asymp. Sig. (2-tailed) &, 124 &, 271 &, 226 \\
Exact Sig. [2* (1-tailed &, $131 \mathrm{~b}$ &, $286 \mathrm{~b}$ &, $231 \mathrm{~b}$ \\
Sig.)] & a. Variable Grouping: ESOP Issuance \\
\hline b. Not corrected for ties. \\
\hline
\end{tabular}

Based on the results of the table above shows that the Asymp Sig value for all performance proxies is greater than 0.05 which means it can be concluded that there is no difference in the company's financial performance when issuing an ESOP and not issuing an ESOP.

\section{Discussion \\ Employee Stock Ownership Program Testing Results on Company Financial Performance}

Based on the results of research that has been done, the ESOP variable which is proxied by the proportion of ESOP has no effect on ROE, NPM and OPM. This is indicated by a beta value of -1.504 and a significance value of 0.407 on the dependent variable ROE. In the NPM variable the beta value is -1.082 and the significance value is 0.565 . While the OPM beta value of 2.204 with a significance value of 0.117 .

These results show the same conclusions as the research conducted by Long 2013 which shows the results that the application of ESOP in the company has no effect on the company's financial performance. These results indicate that the granting of ESOP to employees with either high or low amounts cannot motivate employees to improve the company's financial performance as proxied by the ROE, NPM, and OPM ratios. Many employees are not interested in stock-based incentives and are more interested in cash incentives.
This happens because of the uncertainty of the benefits to be gained with the ESOP program compared to cash incentives. In addition, this stock-based incentive program is more in demand by top-level management than lower-level employees.

\section{Execution Price Test Results on the Company's Financial Performance}

Based on the results of research that has been done the variable execution price affects ROE and NPM but does not affect OPM where the significance value on OPM shows a value of 0.117 , which means the execution price has no effect on OPM. While the ROE and NPM results of the analysis are shown by looking at the beta value and the significance value of the ROE which is valued at 1.042 and 0.009 . In NPM beta values and their significance are 1,016 and 0.013. At the significance value below 0.05 , it can be concluded that the execution price influences the performance which is proxied by ROE and NPM. The results of this study are in line with research conducted by Kameswari (2014) who found that execution prices have a positive effect on performance.

In this case it can be seen that employees can be motivated to perform better in accordance with the implementation price (execution price) set by the company. if the execution price set by the company is below the stock market price at the time the ESOP is issued, each employee will try to increase the market price of the company's shares so as to enable employees to get a large profit from the implementation of the ESOP. The stock market price will increase when the company's financial performance is always increasing, so as to attract investors to be able to invest in the company. With so many investors interested in investing in companies, the company's stock market price will also increase.

\section{Results of Testing of Financial Performance Differences in Companies that Implement ESOPS when issuing ESOPs and not issuing ESOPs}

Based on the results of testing that has been done there is no difference in the company's financial performance which is proxied by ROE, NPM and OPM when the company issues ESOP and when the company does not issue ESOP as indicated by the results of the Man Whitney test where the test results are 0.124 in ROE, 0.271 in NPM and .226 on OPM. These results are smaller than the alpha value of 0.05 so it can be concluded that there is no difference in the company's financial performance when issuing ESOPs and not issuing ESOPs. The results of this study are the same as the results of a study conducted by Pandansari (2010) who found that there was no difference in the company's financial performance when the company issued an ESOP and did not issue an ESOP. 
This can occur because when a company that issues an ESOP can motivate its employees to improve company performance. However, the implementation of this ESOP will cause an increase in company costs, namely the compensation costs of implementing the ESOP so that it can reduce company profits. So it can be concluded that although the application of ESOP can increase employee motivation to improve performance, there are costs that must be incurred by the company in connection with the implementation of ESOP so that there is no difference in the company's financial performance when issuing an ESOP and not issuing an ESOP.

\section{CONCLUSION}

Based on the results of the research and discussion presented in the previous chapter, the following conclusions can be drawn:

1. The amount of ESOP given (Proportion of ESOP) has no effect on ROE. This can be explained by the results of the statistical test $\mathrm{t}$ which produces a significance value of $0.407>0.05$

2. The amount of ESOP given (Proportion of ESOP) has no effect on NPM. This can be explained by the results of the statistical test $\mathrm{t}$ which produces a significance value of $0.565>0.05$

3. The amount of ESOP given (Proportion of ESOP) has no effect on ROE. This can be explained by the results of the statistical test $\mathrm{t}$ which produces $\mathrm{a}$ significance value of $0.347>0.05$

4. Execution Price has a significant effect on ROE which is explained by the results of the statistical $t$ test which produces a significance value of 0.009 $<0.05$

5. Execution Price has a significant effect on NPM which is explained by the results of the statistical $t$ test which produces a significance value of 0.013 $<0.05$

6. Execution Price does not have a significant effect on OPM which is explained by the results of the statistical t test which produces a significance value of $0.117>0.05$

7. There is no difference in the company's financial performance which is proxied by ROE, NPM, and OPM when issuing ESOP and not issuing ESOP which is explained by the results of the Man Whitney test where the Asymp value. Sig (2-tailed) ROE, NPM, OPM of $0.124 ; 0,271$; and 0.226 , where all three amounts are greater than 0.05

\section{REFERENCE}

Aboody, David. Nicole Bastian Johnson. and Ron Kasznik. 2010. Employee Stock Options and Future Firm Performance: Evidance from Option Repricings. Journal of Accounting and Economics, Vol 50, 74-92
Anwar, Azwar. Zaki Baridwan. 2006. Effects of Employee Stock Option Plans (ESOPs) to Performance and Firm Value: Empirical Study at JSX. 9th National Accounting Symposium Padang

Anthony, Robert N. Vijay Govindarajan. 2004. Mangement Control System. Jakarta. Salemba Empat

Astika, Ida Bagus Putra. 2005. Benefits and Factors that Influence the Adoption of Stock Option Programs in Public Companies Listed on the Jakarta Stock Exchange. Journal of Accounting, Faculty of Economics, Udayana University

Bacha, Obiyatulla Ismath. Sharifah Raihan Syed Mohd Zein. Et al. 2009. Granting Employee Stock Options (ESOs), Market Reaction and Financial Performance. Asian Academy of Management Joutnal of Accounting and Finance. Vol 5 No. 1, pp. 117-138

Bapepam 2002. "Study on the Implementation of ESOPs of Public Companies in the Indonesian Capital Market." finance department of the Republic of Indonesia

Bathala, Chenchuramaiah T. Kenneth O Moon. Ramesh P Rao. 1994. Managerial Ownership, Debt Polivy, and the Impack of Institutional Holding: An Perspective Agency. International Financial Management Association. Vol 23. No 3. Pp 38-50

Bodie, Zvi. Alex Kane. Alanj Marcus. 2006. Investment; Investation. Jakarta. Salemba Empat

Budiman, Arip. 2017. The Effect of Execution Price and ESOP on Company Performance with Managerial Ownership Moderation. Journal of Accounting and Research. Vol6. No. 7

Brigham, Eugene F. Michael C. Ehrhardt. 2009. Financial Management: Theory and Practice Twelfth Edition. The USA. Thomson South Western.

Eisenhardt, Kathleen M. 1989. Agency Theory: An Assessment and Review. Academy of Management Review. Vol 14. No 1. pp 57-74

Elton, Edwin J. Martin J Gruber. et al. 2014. Modern Portfolio Theory And Investment Analysis. The USA. John Wiley

Freeman, Steven. 2007. Effect of ESOP Adoption and Employee Ownership: Thirty Years of Research and Experiance. Organinizational Dynamic Working Paper. 7-01

Ghozali, Imam. 2011. Application of Multivariate Analysis with IBM SPSS 19. Semarang Program. Diponegoro University Publisher Agency

Gitman, Lawrence J. 2009. Principles of Managerial Finance. Boston. Pearson Prentice Hall

Hasibuan. SP Malayu. 2012. Human Resource Management. Jakarta. Earth Literacy 
Fitri Handayani dan Yurniwati, Analysis of The Influence of Employee Stock Ownership Program (ESOP) Application of

Indonesian Institute of Accountants. 2015. Statement of Financial Accounting Standards (PSAK) No 53 Stock Based Payments. Jakarta

Iqbal, Z. And HS Abdul. 2000. Stock Price and Operating Performance of ESOP Firms: A TimeSeries Analysis. Quarterly Journal of Business and Economics. Vol 39. No 3. pp 25-47

Jensen, Michael. William Meckling. 1976. Theory of The Firm: Managerial Behavior, Agency Cost and Ownership Structure. Journal of Financial Economics. Vol 52. No 4

Kameswari, Luh Putu Lisa Anastasia. Ida is good, Putra Astika. 2014. Effect of Number of Stock Options and Price of Execution on Company Performance. EJournal of Udayana University Accounting

Keown, Arthur J. John D Martin. et al. 2010. Financial Management: Principles and Their Application. Jakarta. PT Index

Kim, Kyong Yong. 2016. Employee Ownership and Firm Performance: A Variance Decomposition Analysis of European Firms. Journal of Business

Klein, Katherine J. 1987. Employee Stock Ownership and Employee Attitudes: A Test of Three Models. Journal of Applied Psychology Monograph. Vol 72. No. 2. 319-332

Long, Choi Sang. Mahanra Rao. and Ajagbe Akintunde Musibau. 2013. Can Employee share Option Scheme Improve Firm's Performance? A Malaysian Case Study. Information Management and Business Review. Vol 5. No 3, pp. 119-128

Messier, William F. Steven M Glover. Douglas F Prawitt. 2005. A Systematic Auditing and Assurance Service. Jakarta. Salemba Empat

Pandansari, Ghea Maharani. 2010. Comparative Analysis of Company Performance Before and After Holding an Employee Stock Ownership Program (Esop) with Companies Not Holding Esop. Thesis. Surakarta sebelas Maret University

Bapepam Regulation No. IX D.4 concerning Issuance of Shares without Pre-emptive Rights is accessed on www.ojk.go.id

Bapepam Regulation No.IX.A.7 concerning Securities Allotment in Public Offering is accessed at www.ojk.go.id

Pugh, William N. Sharon L. Oswald and John S. Jahera 2000. The Effect of ESOP Adoption on Corporate Performance: Are There Really Performance Change? ". Journal of Managerial and Economic. Vol 21: 167-180

Santhy, Rayhita. IB Putra Astika. 2015. Differences in Company Performance Before and After Employee Stock Option Plan Grants. Ejournal of Accounting at Udayana University

Now, Uma. 2011. Research Method for Business Issue 4. Jakarta. Salemba Empat
Sesil, James C. Maya K Kroumova. 2005. The Impact of Broad Stock Based Options on Firm Performance: Does Firm Size Matter? Working Paper

Subramanyam, KR John J Wild. 2009. Financial Statement Analysis. McGraw-Hill International Edition. The USA. McGraw Hill

Raymond A. Noe. (2011). Fundamentals of Human Resource Management. The USA. McGrawhill Irwin.

Watt, Ross L. Jerold L. Zimmerman. 1990. Positive Accounting Theory: A Ten Years Perspective. The Accounting Review. Vol 65. No 1.pg 131 